\title{
Pension Accounting Treatment: A Review of the Literature
}

\author{
Augustine C. Arize ${ }^{1}$, Ioannis N. Kallianiotis ${ }^{2}$, John Malindretos ${ }^{3}$, Denise Stabile ${ }^{4} \&$ Demetri Tsanacas $^{5}$ \\ ${ }^{1}$ Department of Economics and Finance, College of Business, Texas A\&M University, USA \\ ${ }^{2}$ Department of Economics and Finance, Arthur Kania School of Management, University of Scranton, USA \\ 3 Department of Economics, Finance, And Global Business, Cotsakos College of Business, William Paterson \\ University, USA \\ ${ }^{4}$ Department of Economics and Finance, Cotsakos College of Business, William Paterson University, USA \\ ${ }^{5}$ Department of Business Administration, School of Social Sciences and Professional Studies, Ferrum College, USA \\ Correspondence: John Malindretos, Department of Economics, Finance, And Global Business, Cotsakos College of \\ Business, William Paterson University, USA
}

Received: July 13, 2017

doi:10.5430/afr.v6n3p169
Accepted: August 10, 2017

Online Published: August 21, 2017

\begin{abstract}
In this research study we explain the basic content of Financial Accounting Statement number 87 (FAS \# 87). We also give evidence for its early adoption by diverse firms and analyze the reasons for its early adoption. Finally, we present the state of pension accounting before the adoption of FAS \# 87.
\end{abstract}

Keywords: Accumulated benefit obligation, Financial accounting for pensions, Projected benefit obligation, Interest cost, Service cost, Pension cost, Vested benefit obligation

\section{Introduction}

In December of I 985 the Financial Accounting Standards Board issued Statement of Financial Accounting Standards No. 87 in an attempt to overcome some of the shortfalls of earlier standards for pension accounting under FAS No. 36 and APB Opinion No. 8. (Note 1)

Controversy over this Statement reached a level not previously experienced by the FASB and continued over the course of 5 years preceding the actual issuance of the statement. The controversy developed over a few issues but primarily centered around the proposal for recognizing a Balance Sheet liability effectively equivalent to the unfunded portion of projected benefit obligations and the method for determining period pension costs.

Many corporate executives believed that by recognizing a pension liability on the balance sheet the perceptions of stockholders, creditors and the market would be negatively impacted. They also anticipated cost increases which would potentially impact market value, negatively.

As a result of the enormous industry response, the FASB revised the statement, requiring accounting methods that would have a less negative impact. The decision of the FASB was based on the arguments presented during the preceding period of controversy. None-the-less, many new complex methods of accounting and reporting resulted. Since the issuance of this statement much research has been conducted on the effects of this accounting standard. This paper is Part I of a two part study which attempts to determine the impact of SFAS No. 87 on Corporate (market) value (Note 2).

Part one contains a review of existing research, including an overview of FAS $87 \mathrm{~m} \mathrm{Section} \mathrm{1,} \mathrm{in} \mathrm{an} \mathrm{attempt} \mathrm{to}$ determine if the following hypothesis is supported:

2. SFAS No. 87- Overview (Note 5)

As stated in FAS 87, the objectives of the Financial Accounting Standards Board in issuing this Statement are as follows:

1.) To provide a better and more consistent unit of measure of net periodic pension cost that is more consistent ("representationally faithful").

2.) To provide a more understandable and comparable measure of net periodic pension cost which would be more useful. 
3.) To provide disclosure to allow users to better understand the extent and effect of the Employer's Employee Pension Plan.

4.) To improve reporting of financial position.

With these objectives in mind they developed FAS 87; which some critics state are the most complex and incomprehensible accounting procedures the FASB had developed to-date.

Many articles have been written just to explain the mechanics of this statement because of it's complexity, so that users of financial statements can understand pension data reported in financial statements.

Many additional articles have been written attempting to both interpret and explain the financial and economic impacts so users can evaluate what they read in financial reports.

Although this standard covers multi-employee, non-US, and defined contribution plans; the most important aspect of the statement is with regard to defined benefit plans and defined benefit plans are the basis of this paper's evaluations.

A summary of the key points of FAS 87 are as follows:

\section{Accounting}

Specific assumptions were identified for determination of pension benefits using the terms of the pension plan itself. Specifically, the benefits formula is used.

Net periodic pension costs are comprised of five components:

1.) Service Cost

2.) Interest Cost

3.) Actual Return on Plan Assets

4.) Amortization of Unrecognized Prior Service Costs

5.) Gain or Loss

Additionally, periodic costs and pension obligations are required to be estimated attributing the cost to periods of employee service.

The projected benefit obligation (PBO) is defined as the actuarial present value, as of a date, attributed by the plan's benefit formula to employee service rendered prior to that date. It considers future compensation levels in the computation.

The accumulated benefit obligation ( $\mathrm{ABO}$ ), as of a date, is defined as the actuarial present value of benefits attributed to employee service rendered prior to that date and is based on current and past compensation levels.

The accumulated and vested benefit obligation provide estimates of the obligation the employer would have if the plan were terminated.

The ABO, PBO and Vested Benefits all include automatic benefit increases and retroactive amendments to the plan.

Since the $\mathrm{ABO}$ and the $\mathrm{PBO}$ are used for different purposes within FAS 87, this difference is significant since the $\mathrm{ABO}$ is usually substantially less than the PBO.

Plan assets are defined as investments that have been segregated and restricted to provide pension benefits. The value of plan assets is calculated as the sum of contributions and amounts earned from investing, less benefits paid. Amounts accrued by the Employer but not yet paid are not included as plan assets.

Only under certain circumstances where the plan has assets in excess of obligations, may the employer withdraw any assets from the plan.

As will be seen, the Board took numerous steps throughout this Statement to smooth pension cost in an attempt to control volatility of the amount reported each period. However, certain of the calculations methods prescribed by the Statement allow enough options and opportunities for variation on the use of key variables (i.,e., Discount Rate), as will be discussed in upcoming sections of this paper, that many contend, violate this objective and actually enhance volatility.

Periodic pension costs are calculated as follows:

1) Service Cost

Actuarial present value of benefits attributed by the pension benefit formula to employee services during the period. 
The measurement of service costs requires use of the "projected unit of credit" actuarial cost method which is a benefit/years of service attribution approach. Prior to FAS 87, alternative actuarial methods were allowed.

The service cost calculation also includes consideration of written and of non-written but substantive commitments to provide future amendments (which increase benefits).

All accounting assumptions must presume the plan will continue, absent any evidence to the contrary.

The service cost component should also reflect future compensation benefits but only to the degree they are attributed by the pension benefit formula. Also, any assumptions as to future economic conditions must be the same for service costs as used in calculating the PBO.

\section{2.) Interest Cost}

The increase in the projected benefit obligation due to the passage of time. It is measured as the present value of the PBO and requires that an accrual be recorded for interest cost at rates used for the assumed discount rate (the assumed discount rate is a current settlement rate as described below).

The assumed discount rates must reflect rates at which the pension benefits could be effectively settled, as of the date of the estimate. FAS 87 identifies the implicit rates in the current value of annuity contracts or those published by the Pension Benefit Guaranty Corporation or rates of return on high quality fixed income investments that are currently available, as appropriate for this purpose. This rate is used for the measurement of the PBO, ABO and Vested Benefit. Since the service cost component is determined by the pension plan formula, the rate additionally affects its value.

\section{3.) Actual Return on Plan Assets}

Is based on the fair value of plan assets at the beginning and end of the period, adjusted for contributions and benefit payments. Fair value equals market value where an active market exists, as of the measurement date. Where no market exists fair value is the amount that one could expect to receive from a "willing" buyer, other than for a forced or liquidation sale. To estimate fair value similar investments with an active market may be considered. Also, a forecast of expected cash flows should be considered, discounted by a current interest rate equivalent to the risk involved.

\section{4.) Prior Service Cost}

The increase in the PBO at the date of the amendment. Retroactive plan amendments are not required to be recognized as a prior service cost, in the year of amendment, since it is assumed that the benefits will be provided into the future for active employees (active as of date of amendment). So this expense is amortized into pension cost over future service periods, in equal amounts. If most or all employees covered by the plan are retired then amortization is based on their remaining life expectancy.

As an exception to this rule, accelerated amortization is used when situations indicate benefits of the amendment will be realized during a shorter period and there is evidence and/or a historical trend to support that fact.

Also, when an amendment reduces rather than increases the PBO, the reduction is first used to reduce any previously existing service cost and only any excess is amortized to pension cost.

5.) Gains or Losses Changes in the amount of either the PBO or the plan assets resulting from actual experience different from that assumed and from changes in assumptions. It includes realized as well as unrealized sources of gain or loss.

Total gains or loss are not recorded as pension cost during the period in which they occur. Instead, first the expected return is determined using the expected long term rate of return. Then the market value of plan assets is determined. Finally, the difference between the two is calculated and the determination as to whether or not amortization is required to be recorded, is decided.

An amortization of an unrecognized gain or loss (excluding asset gains \& losses not yet reflected in market value) is included in pension cost if, as of the beginning of the year, the recognized gain or loss exceeds $10 \%$ of the greater of the PBO or the market related value of plan assets. (This 10\% window is referred to as the "corridor".)

If amortization is required, the minimum that should be recorded is calculated as - the excess divided by the average remaining service period of active employees (or again, if most or all are retired; the remaining life expectancy is used).

The following methods must be used to determine expected and market values:

-The expected long -term rate of return must reflect the average rate of earnings expected on the funds invested or to be invested. Returns available for re-investment must also be considered in the average rate.

-Market value equals fair value or a calculated value recognizing changes in fair value over 5 years, maximum. If 
calculated in this fashion the calculation methods must be used in a consistent, systematic and rational fashion (i.,e., 5 year moving average value for equities). Also, different asset classes may be valued differently as long as the method for determining value remains consistent.

Lastly, period pension cost will also include any amortization of the unrecognized net gain or loss from previous periods.

6.) Amortization of the unrecognized net obligation (and loss or cost) existing at the date of initial application of FAS 87

The difference between the PBO and the fair value of plan assets, plus any previously recognized unfunded accrued pension cost, or less any previously recognized prepaid pension cost; amortized on a straight- line basis over the average remaining service period of employees who receive the benefits. However, if that service period is less than 15 years, the employer may elect to use 15 years. If the employees who receive the benefits are mostly or all retired, then their average remaining life expectancy is used. (This value may also result in a cost reduction when the pre-FAS 87 asset is greater than the pre-FAS 87 obligation.)

Plan assets and liabilities are recognized as follows:

1.) A liability is recognized when net periodic costs exceed the amounts the employer has contributed to the plan.

2.) An asset is recognized if net periodic pension cost is less than the amount of contributions.

3.) Also, if the $\mathrm{ABO}$ exceeds the fair value of plan assets the employer must recognize in his Balance Sheet, a liability that is at least equal to the unfunded ABO. Therefore, recognition of additional "Minimum Liability" is required if the unfunded $\mathrm{ABO}$ exists and an asset has been recognized as prepaid cost and the liability already recognized as unfunded $\mathrm{ABO}$, or when no accrued or prepaid pension cost has been recognized.

When a minimum liability is required, the offsetting transaction to the books of account, is not, however, expense. Instead the debit is to an intangible asset provided that the asset does not exceed the amount of unrecognized prior service cost. If it does exceed this amount, then the excess is recorded against equity (a reduction) net of any tax benefits that result from considering any such loss as a timing difference.

The intangible asset and the separate component of equity are then eliminated or adjusted for preparing financial statements.

\section{Financial Reporting and Disclosure}

1.) A description of the plan identifying employee groups covered, type of benefit formula, funding policy types of assets held, significant non-benefit liabilities (if any), and the nature and effect of significant matters affecting comparability of all periods presented.

2.) All components of period pension cost are shown separately for service cost, interest cost and actual return on plan assets. All other components are shown net.

3.) A schedule reconciling the funded status of the plan with amounts shown on the Balance Sheet. The following items must be shown separately:
a.) Fair value of plan assets
b.) PBO, identifying $\mathrm{ABO}$ and Vested benefit obligations
c.) Unrecognized prior service cost
d.) Unrecognized gain or loss (including asset gains of losses not yet reflected in market related value)
e.) Unrecognized net obligations or net assets existing at the date of adoption of FAS 97
f) Amount of additional (minimum) liability recognized

g.) Net pension asset or liability (net result of combining the above) recognized in the balance sheet.

4.) The weighted average assumed discount rate and rate of compensation increase used to measure the PBO and the weighted average expected long term rate of return used to measure plan assets.

5.) Amounts for types of securities of the employer and related parties, included in plan assets and the approximate amount of annual benefits covered by annuity contracts issued by the employer and related parties. Also, any alternative amortization methods used must be disclosed. For prior service cost, and gains and losses, or any situation for which a substantive commitment exists to provide a future plan benefit amendment that is not documented in the plan, the obligation must be disclosed and the nature of the obligation defined. 


\section{The History of SFAS 87}

FAS 87 is a unique accounting standard in that it was originally issued in 1984 in a preliminary document entitled "Preliminary Views". This was prior to issuing the formal Exposure Draft, which is the standard preliminary draft that the FASB issues prior to releasing the actual standard.

As originally issued, the "Preliminary Views" document proposed a method of accounting for defined benefit plans which was a major change from Opinion 8, the previous standard for pension accounting.

The two primary changes were as follows:

I.) The method of measurement for period expense

2.) A change in the manner of reporting of the size and effects of pension obligations on the corporation's balance sheet.

The standard as originally proposed required that a sponsoring corporation report the projected benefit obligation as a liability in the firm's balance sheet. Also, with regard to period costs, the measurement of same was directly related to the projected pension benefit obligation.

Previously, under Opinion 8, this liability, along with pension assets were not recorded on the books of account. Therefore, this document caused a great commotion in industry.

In the five day public hearing that was held to review and discuss the "Preliminary Views" accounting methods changes, there was intense negative feedback from industry leaders. Some even stated that they would refuse to use the accounting method and would not recognize the liability in their balance sheet (Note 6)

As a result of the opposition, the FASB backed off of its preliminary requirements and by time the exposure draft was issued, a much milder version of accounting requirements was specified.

Although the FASB held firm to requiring that a pension liability be recognized in the balance sheet, they much lessened potential P\&L impacts by requiring that only a minimum liability be recognized and continued to hold most of the obligation and asset valuation off the balance sheet, as in the past.

\section{Current Financial \& Economic Considerations}

As becomes apparent when one reviews SFAS 87, there are many areas of complexity involved with both the accounting and reporting of pension plans from the perspective of the corporate sponsor of the plan.

Key areas of concern, with regard to the impact of this statement on the market price of the stock of the adopting firm, are: interest rates, timing of adoption, period cost calculation methods, balance sheet liability reporting, disclosure information, the extensive use of deferrals and amortization in order to smooth P\&L impacts, cash flow impacts and credit issues.

Various studies have been done regarding these subjects with the most noted issues being changes that are either evidenced in the $\mathrm{P} \& \mathrm{~L}$ or the methods of calculating and determining those charges.

In Section I, we attempt to describe the issues, as identified in the literature, in relationship to the potential influence each item may have on market value.

In order to more clearly present the issues, we have segmented this section of the paper by major component of pension cost or critical issue, where more appropriate.

\section{General Trends}

In a study conducted by M. Merryman, published in The Woman CPA, Winter-I990 the objective was to determine the impact to the P\&L, that resulted from adopting FAS 87 . Her sample consisted of 100 publicly traded companies, and out of the total sample 69 were "Forbes 500" companies. Only 31 were smaller and less well known.

Out of the total sample, 72 had adopted early. Only 28 implemented later when required by the Statement. Seventy-one of the seventy-two were able to reduce expense under the new rules of FAS 87, or the change to their P\&L was not material. Twenty-eight of the sample were actually able to report pension income as a result of the new accounting methods. According to Ms. Merryman, the favorable results were primarily due to the rule in FAS 87 which allows the offsetting of the return on assets against period expense.

Sixty-five companies reported a decrease in pension expense as compared to what they would have reported under the old rules of APB Opinion 8. Only three companies experienced an increase in pension expense. For the companies whose pension expense decreased, 13 companies reported a decrease of over $100 \%$, and one company had an increase in net income of $121 \%$. This is highly significant to the P\&L's of those specific firms experiencing such alterations and 
explains why this particular Statement was and still is a controversial subject to the financial community.

With respect to the new liability reporting required by SFAS 87, of the 100 companies included in the study only 32 had unfunded obligations as of the date of adoption. Of the 32 only 19 would have been required to report a "minimum liability" as required by 87 , had that rule not been authorized by the FASB for delayed application. However, although these 19 companies would have been required to report a minimum liability, the amount that would have had to have been recognized was an immaterial percentage of their total assets. Finally, with regard to this subject, it should also be noted that based on Merryman's findings, only one company in the entire sample elected to adopt the minimum liability standard early.The final item examined by Ms. Merryman was the disclosure requirement. Her findings indicate that out of the total sample population all but three had adequate disclosure.

In conclusion, she stresses concern over the financial impact on the net income of firms during the transition period. She states that financial statement users should be careful of the effects that FAS 87 had on net income, especially when they use that information to perform prior year comparisons.

The inference in her statement is that most users could overlook these "accounting methods" changes and be misled as to the actual performance of the company during the period. It appears that the income shown in the P\&L is not true income, with regard to items which changed as a result of applying the new Statement.

With regard to the implications of the changes FAS 87 had on the balance sheet, she states that her findings are inconclusive and that more time will be needed to determine if the new reporting requirements actually do help improve financial reporting. She states that ultimately the usefulness of the new balance sheet reporting requirements will really depend on how users of financial statements actually view pension assets and obligations. In this regard one could speculate that there is still, after adoption of FAS 87, too much left off the balance sheet for it to do much good and that without the footnote disclosure required by this statement, the balance sheet items themselves could be perceived to be relatively unimportant.

However, others could argue that by requiring recognition of at least the minimum liability for the unfunded liability the FASB has taken at least one step in the right direction. However, given the large window of time over which no liability needed to be recorded and the prescribed method of determining value (Note 7) this information may not be enough and may be increasingly misleading for users of financial statements for determining the true value of the pension obligation.

\section{Projected Benefit Actuarial Cost Method}

As was stated earlier, under FAS 87 only one single actuarial cost method is permitted for determining service cost; compared with multiple methods that were permitted under Opinion 8.

The method authorized by FAS 87 was the accrued benefit method which allows for the firm to apply the cost of the benefits over the Employees entire work life, and which effectively keeps the cost for any given period lower or higher than it would be using other previously allowed methods, depending on the firm's choice of methods.

In order to examine the impact the accounting methods change would have on a firm, many researchers believed it was first necessary to first examine why corporations selected the method of costing that they did, originally, under Opinion 8.

In a study done by VanDerhei and Jeanette, they examined whether or not prior pension accounting choices had any rationality. Also, they wanted to determine why there was all the controversy that there had been over this particular aspect of FAS 87, since earlier research had indicated that most firms already used the accrued benefits method under Opinion 8.

In order to determine what the implications of adoption were for firms, they examined companies in two scenarios:

The first consisted of companies who had previously used the projected benefit actuarial cost method, under which pension benefits would be expensed more rapidly than using the accrued benefit method required by FAS 87 . They assumed these companies to have political reasons for management to have decided to use the actuarial method which kept cost greater and thereby lessened profits.

The second consisted of companies who had previously been using the accrued benefits method for pension accounting and the group for which one would assume FAS 87 would have no material impact on their P\&Ls (with regard to this particular requirement of the new accounting method). They assumed this group to have debt constraint guidelines to satisfy hence they wanted to keep their P\&L costs lower.

Early studies indicated that a theory seemed to hold true, which indicated that the relationship of the labor force market 
within which a firm functioned, combined with the particulars of the firm, determined the choice of accounting methods selected by that firm and such was the case with pension actuarial cost methods chosen .

For firms who were subject to government controls (i.e. rate control) or other political influences

(i.e. Unions), the tendency would be to employ accounting methods which caused costs to be higher, rather than lower, so that attention was drawn away from the firm rather than towards it. (Note 8)

For firms subject to debt covenants on their financing agreements, firms would need to keep costs as low as possible to keep financial ratios as high as possible.

Their findings indicated that their assumptions held true and that prior to adopting FAS 87 firms generally considered political governmental repercussions and debt constraints (covenants on existing loan agreements) along with P\&L impacts. (Note 9)

Therefore, they conclude that for those who needed to keep their costs higher, FAS 87 would definitely impact them and they would therefore tend to adopt later rather than earlier.

With regard to debt covenants they found that it was more likely that these firms would have already been using the accrued benefit actuarial cost method, therefore the impact of FAS 87 in this regard, would be less for them.

\section{Debt-Covenant Hypothesis}

Much of the controversy over FAS 87 refers to the "Debt-Covenant" hypothesis. Under this hypothesis many corporations argue that SFAS 87 (as well as other similar accounting standards recently proposed or implemented) because of its requirement of recognition of a pension liability on the balance sheet, and because of its requirement for disclosure of the larger projected benefit obligation (vs. only disclosing the ABO), causes negative perceptions of the financial position of the company by creditors and subsequently the market, because of the changes that occur in financial ratios which are frequently covenants of debt agreements and also used for market analyses.. Also, for some companies, recognition of a significant pension liability could put them in technical default of their loan agreements.

In a study conducted by V. Gopalakrishnan and Timothy F Sugrur (Note 10), they examine whether or not this hypothesis held true.

Based on the sample used in their study, 46 covenants were found to be based on accounting information. Out of these covenants 36 (or 76\%) were materially impacted by the accounting changes of FAS 87 . They found that for $65 \%$ of the sample firms were subject to technical violations or had experienced substantial reductions in debt covenant slack. However, they could find no significant stock market reaction to same and because of this could not support the hypothesis. So while the availability of credit may be impacted, the firm's market value would not be. Instead it appears that the market place adjusted for the change in ratios that the accounting method caused.

To determine if the minimum liability and projected benefit disclosure had any impact on perceptions of debt the results of a small experiment conducted by R. Harper, Jr.; William G.Mister and Jerry R. Strawser, which appeared in the Journal of Accounting Research during the autumn of 1987, was reviewed. SFAS 87 pension disclosure was examined in this study with respect to the impact it made on both experienced and inexperienced readers perception of a firm's debt.

Their findings indicate that users do not treat footnoted pension information in the same manner as they treat balance sheet information, and that it is somewhat more pronounced for the less sophisticated user.

In their experiment, 51 bankers and 82 undergraduate accounting students attending a lending seminar were given one of two versions of a hypothetical company's balance sheet and were asked to indicate the numerator and denominator of the company's debt to equity ratio. In one version the pension liability was included in the balance sheet. In the other version it was included in the footnotes.

The most frequent response was to use the liabilities as reported in the balance sheet. Only $10.8 \%$ of those receiving the pension liability in the footnote disclosure included it in the debt numerator. Also, based on the statistics, they could not prove that the impact of the disclosure was different depending on whether or not the users were more or less sophisticated.

This study indicates that the disclosure of the projected benefit may not have had as great an impact on creditors perceptions as industry anticipated but that where a minimum liability is recorded in the balance sheet, it is accepted as such and used in credit evaluations. 


\section{Interest Rates}

Interest rates are possibly the most significant aspect of FAS 87 since for determining key items of cost and equity the current market rate is used and since this rate could fluctuate significantly from period to period, both the P\&L and Balance sheet, as well as the value of off balance sheet items, will be impacted by any rate changes and that impact has the potential to be material.

Also the subject of interest rates is additionally important because if the correct rate is not used to value an investment (asset) or liability (i.,e.,. long vs. short term, fixed income vs. equity, etc.) an improper valuation will occur.

As was stated in Section Two of this document, market value is used for the "assumed rate" to determine the interest cost component of pension cost, service cost component (it's in the benefit formula), and the accumulated, vested and projected benefit obligation amounts. The FASB specifies where these rates should be taken from (See Discount Rate Section of the Overview). So every pension element will be affected by a rate change in the marketplace. This links pension cost very closely to the current economic conditions.

Some have argued that not only will using current rates cause wild fluctuations but also that the current market rate is an inappropriate rate for valuing these pension elements given the nature and duration of the assets and obligations themselves. It has also been argued that even though the rate specified in FAS 87 aren't the best rates to be used; they should still be used consistently. Some are arguing that this is not happening and inferring that pension costs are being manipulated.

In a recent article that appeared in Financial Executive, Jan.-Feb. 1994, written by two partners in Ernst \& Young"; they discussed the "happy state of affairs" of companies who had adopted FAS 87 in 1986. 1986 was a year during which high quality corporate bonds were yielding an all time high rate of $10 \%$. Even abnormally high, according to the article, were 10-year Government bonds which were also yielding rates in the range of $9.25 \%$.

According to this survey, it appears that those who adopted in 1986 used this rate for discounting their pre-FAS 87 pension obligation as well as their pension costs and obligations of the period. Which effectively kept period cost low and allowed for a more favorable comparison of pre-existing assets to preexisting obligations which could (and did, in very many cases) result in establishing a pre-adoption asset (vs. liability) that could be amortized favorably into the $\mathrm{P} \& \mathrm{~L}$ over future years, thereby further reducing pension costs.

Additionally, their study indicated that although Aaa and Aa bonds decreased from 10.1\% in 1985 to $8.1 \%$ in 1992, there was no noticeable change in the average discount rates used for pension accounting throughout the period. Statistics indicate that most companies used an average of $8.6 \%$ to $8.2 \%$ throughout the period.

The writers conclude that these companies probably used lower rates initially, such as those published by the PBGC to more closely match their pre-FAS 87 assumptions and then later, when bond rates declined, switched assumptions from PBGC rates to using Aaa or Aa bond rates, which would be higher than PBGC rates, but which had themselves decreased as the years went on. Therefore, no volatility appears in corporate P\&L's for these years, with regard to interest rate impacts.

The writers state that their survey indicates the precise lack of volatility of the FAS 87 market -rate concept of valuation for pension obligations and pension cost. They also indicate that they expect this would also hold true into the future.

However, the only reason there was no volatility in pension cost, as there should have been under the accounting methods established by FAS 87, was because the firms changed the source of the rates and therefore ensured that the rates used would deliver the effect they wanted; which was to lower pension cost. This means that since they held their cost and present value of obligations fairly constant, this is not the correct value, if one assumes the market rate to be the correct rate to use to value pension liabilities. The result is that cost and obligation as reported are both fictitiously low for years during which interest rates were high, and fictitiously higher for years during which interest rates were lower. And while over a period of years it may all average out, any particular year you cannot obtain the correct value from financial statements under FAS 87 accounting. Also, if rates are continually altered, the P\&L will never experience the offsetting to market value that presumably the FASB anticipated would occur.

It appears that the Financial Accounting Standards Board left a loophole in the rules when they did not mandate (and do not enforce) consistency with regard to rate assumptions.

A second point of this article was to point out that depending on the investment fonn in which the plan assets were held, using fixed-income rates to discount pension obligations could cause liabilities to be overstated, since over time if plan assets were held in equities, generally, a higher rate of return would be expected. Since this was not the rate being used 
to discount the obligations, generally they would tend to be overstated.

In an earlier article (I 990) that appeared in Financial Reporting, R. Herdman and R. Meany of Ernst \& Young discuss the results of a survey they ran in 1988, which supports the later study discussed above, which indicated that in practice, finns were not using the interest rates authorized by the FAS B for calculating net present value of pension obligations. In the article R. Herdman and R. Neary state that while FAS 87 requires the use of only certain current settlement rates; long-term fixed income, or armuity rates published by the PBGC, for discounting; in actual practice these appear not to be the rates being used.

In their study of IOO companies during I988, they found the average discount rate was $8.87 \%$, indicating a slight increase from the average rates of $8.8 \%$ used in 1987 and $8.36 \%$ used in I986. They found this increase to be more comparable with rates on long-term treasury bonds which increased from an average of $9.03 \%$ at I2/3 I/87 to $9.08 \%$ at $\mathrm{I} 2 / 3 \mathrm{I} / 88$.

On the other-hand PBGC rates (which are appropriate to use according to SFAS 87) decreased from $8.25 \%$ in 1987 to 7.75 in 1988.

The authors state that because interest rates have an inverse effect on the pension obligation this is very important. When the interest rate goes up the PBO goes down resulting in lower service cost (partially offset by the interest cost component which uses this same rate) and when rates go down the inverse occurs.

Based on their survey they found 34 companies had changed their discount rate assumptions in I988. 20 companies increased the rate and I4 reduced the rate, from rates used the previous year, thereby helping to explain why their 100 company sample displayed such different rate changes from that change which the Pension Benefits Guarantee Corporation rates indicated should occur.

They also determined that the average future compensation rate increase used by companies in their survey was $6.2 \mathrm{I} \%$ in I 988 and 6.2 and 6. I8, respectively for I 987 and I 986. Again an increase over prior year rate assumptions. Only II companies changed their assumptions in 1988; 5 companies decreased their rates and 6 increased as compared to 1987 when 22 companies changed their rate assumptions for future compensation increases, indicating a decline.

Expected long-term rates of return on plan assets averaged 9.06\% in 1988 as compared to $8.93 \%$ in 1987 and $8.94 \%$ in 1986. 24 companies changed their rates in 1988 vs. 25 companies who changed their rates in 1987.

Herdman and Neary indicate concern over the volatility of pension expense based on the interest rate fluctuations and assumption changes inherent in FAS 87. They state that although the rate changes were minor in 1988 for the companies they surveyed, these companies averaged a pension cost decrease of $20 \%$ which is a wide variation.

28 of the companies surveyed actually reported a savings of $100 \%$ or more for pension cost and 14 experienced a savings of between $50 \%$ and $99 \%$.

In addition to the reasons cited above (interest rate \& rate assumption changes) plan amendments and termination's/curtailments also were important in achieving the pension cost savings identified above.

Other trends identified in their survey are as follows:

1.) Reported pension income vs. expense- 41 companies in 1988 had income, compared to 39 in 1987 and 34 in 1988.

2.) Pension income was not significant, on the average it was less than $0.21 \%$ of 1988 revenues for the 100 companies in the survey. Also, although increasing, pension expense was not significant, running at, on the average, $0.31 \%$ of revenues in 1988 vs. $0.28 \%$ in 1987 and $0.23 \%$ in 1986 .

3.) Generally, all plans were well funded. The average ratio of plan assets to the present value of projected benefit obligations was $130 \%$ in 1988, compared to $129 \%$ in 1987 and $128 \%$ in 1986 . However, 16 companies disclosed that the value of present assets was not sufficient to cover the present value of PBO in 1988 vs. 13 in both 1987 and 1986.

The minimum liability rule went into effect 1 st Qtr. 1989. 5 of the 100 companies adopted minimum liabilities at $12 / 31 / 88$. Minimum liabilities ran from $\$ 2$ million to $\$ 73$ million for those reporting same in the survey.

The authors conclude that there was minimal volatility during this time period and they attribute most of it to the economy. But they don't mention the importance of the assumption changes, the termination's and the amendments which may have been more significant in stabilizing pension costs during the period.

One concern that arises as a result of the above information, is that if companies had already begun manipulating assumptions during a period of low volatility of high interest rates, and using other means at their disposal such as plan terminations to influence their P\&L's favorably; what do they intend to do when interests rates move drastically (such 
has been the case in recent years)? Particularly when rates drop?

In an earlier article ("The Mad, Mad World of FAS 87"; author, H. Rosenberg), that appeared inThe Institutional Investor, Oct. 1987; the subject of interest rates and the economy is again discussed.

Solomon Brothers was quoted as saying the bull market left the FAS 87 Adopters "sitting pretty", with regard to funding. The collective asset to liability ratio of the 500 top companies in the US was $197 \%$ as of September, I 987 , which is incredibly high.

Taking a somewhat novel approach (compared to the earlier accounting firm authors' whose study was presented earlier), Rosenberg contends that the whole problem surrounding FAS 87 is that it requires an entirely new perspective.

He contends that in the past most companies disregarded the concept of duration matching for pension investments because liabilities were predictable. However, under FAS 87 liabilities are not predictable because each year the current market rate must be used for valuation.

He points out that the average pension obligation has a duration of 9 to 13 years and changes inversely by 9 to $13 \%$ with every percentage point shift in interest rates.

He also points out that most pension investment portfolios have shorter durations than their liabilities and if corporations don't match them there will of course be volatility reflected in their financial statements.

This article further substantiates and clarifies the point being made earlier, that FAS 87 by design will generate volatility in financial statements, but it points to a legitimate economic and financial method by which to resolve it --------using a duration matching strategy for pension investments and liabilities.

Interviewing the above along with other literature concerning a firm's choice of interest rates and application of FAS 87 to financial statements, and if determination of market value is a function of income or other items reported in financial reports, it becomes increasingly clear how critical the appropriate method of valuation and selection of the appropriate discount rate is for market valuation purposes.

Since FAS 87 provided much more information with regard to interest rates and their application within the methods prescribed in the statement, the differences between the new and old methods of accounting would be distinguishable for most analysts familiar with those methods and a determination of the impact of the change of accounting methods could be determined and either considered or discounted when determining a proper market value. However, no evidence could be obtained to either prove or disprove this point of market efficiency.

\section{Timing of Adoption}

Very closely related to the subject of interest rates and the important role they play in discounting within SFAS 87 , is the timing of initial adoption of the Statement. Timing is of importance because depending on the state of the economy (as reflected in the interest rates relevant to this accounting method), depending on the corporation's financial condition at the time of adoption and depending on the funding status of the company's pre-adoption pension plan; all factors combined could have either a desirable of undesirable and positive or negative impact on the P\&L at the time of adoption which could be material.

Because the value of the net asset or obligation pre-FAS 87 is established as the base off of which a future expense or income item is recorded to the $\mathrm{P} \& \mathrm{~L}$, it is significant as to whether at the point of adoption the company recognizes a net asset or liability. Therefore, in this regard, given the state of the economy and interest rates, timing is everything. (See interest rates section above.)

Since companies could postpone adoption 1 year or could actually adopt for the year the statement was issued, they had a window of 2-3 calendar years during which they could select to switch methods.

This allowed plenty of time for executives to determine the best time to incorporate the accounting change to achieve the maximum P\&L benefits from adoption based on their forecast of the direction and magnitude of interest rate changes.

As the research shows many companies adopted early and for most who did there was either an immaterial impact on the P\&L or a favorable impact. Few early adopters experienced material loss or expense by implementing the accounting change.

Also, without exception, based on the literature, the primary motivating factor for adopting the accounting change early or late, was profitability. (Note 12)

According to existing documentation, although different motivations, even multiple motivations may have existed for 
the accounting methods change decision faced by businesses during that time period, the above conclusion holds true, regardless of the number and types of analyses that were run. This fact was true, even though varying approaches, models and methods were used by researchers in forming their conclusions and even though the studies were done over the course of 5 years using current or historical data and using foresight and hindsight.

What is even more interesting, when reviewing the literature as of 1995; is the large number of studies that were done to analyze and document adopting companies' motivations. It appears that this was a popular subject not only because of the generic interest of the financial community as to how a financial executive reaches a decision to employ an accounting methods change, given the impacts that may result in financial statements and possibly the market; but also because of the controversy associated with this FAS and the subsequent backing-off of originally proposed changes that the FASB did, when industry leaders created such a controversy (Refer to Section 3). This indicates the concern of the financial community over the influence corporations have over their own governing and standard setting body for accounting purposes is not without merit.

Although issues over the original proposals centered on the negative impacts on Corporate P\&L's and the negative perceptions that would result because of the minimum liability recognition in the balance sheet, as was required by FAS 87 as first drafted; the final version of 87 had the complete opposite effect.

This was evidenced by all who adopted early. Therefore, the dynamics associated with accounting procedure and policy development play an important role in the market-place, as ultimately they may lead to factors that influence stockholder wealth via market-valuations done from accounting data conforming to accounting standards which may not have been appropriately designed, all for the wrong reasons (political).

In a study done by M. Stone, in I 988 (Accounting Horizons), she stresses that the significance of her study on timing of adoption is not the identification of those who adopted early, but instead is the number of those whose chose to adopt early and the nature and magnitude of the effects on their P\&L's that the accounting change had.

Her study began with a sample of 650 companies whose data carne from and earlier survey conducted by the Accounting Institute of Certified Public Accountants. Based on the information provided from their survey she identified I 8 companies who actually adopted FAS 87 in I 985, one year earlier than required and 265 companies who adopted in the first year, 1986 (which is considered by all to be early). 365 either did not sponsor a defined benefit plan or applied FAS 87 to their I987 annual reports. This represents 44\% of the sample who adopted early and she projects that number would be greater, if we discounted those who did not have a defined benefits plan and for whom adoption is very less significant.

Stone found that the largest concentration of early adopters were in the chemical industry and the largest percentage of late adopters (99\%) were in the electrical equipment and supplies industry. She found these facts to be interesting but could not identify any pattern as to why it was so.

She did however find that all but $19(<8 \%)$ of the early adopters sponsored at least one plan for which the fair value of assets exceeded the projected benefit obligation and that the average amount of excess was \$165. 5 million. This indicates that future pension expense would be lower for these companies than if they had first adopted 87 at a time when there PBO was greater than their asset value. In this regard the timing of their adoption was extremely important for future P\&L impacts.

Stone also found that $23 \%$ of the early adopters curtailed or terminated their overfunded plans the very same year they adopted and she concludes that invoking the rules of FAS 88 may have also played an important role in the decision to adopt early.

FAS 88 is used to account for plan curtailments and terminations, but it could not be applied until 87 was adopted. While the benefits of curtailment and termination are discussed at various points in this paper, the results of termination of overfunded plans are generally favorable to the sponsor because of the reversion of assets to the company. Since reversion frees the asset, it allows the company to invest or use the funds as they see fit, which may allow for more profitability (as for example, should be the case if they invested it in internally). However, FAS 88 is even potentially more important to industry from a P\&L perspective, because it accelerates the recognition of gain that would otherwise have to be amortized into the P\&L, under the rules of FAS 87. Stone's research uncovered the following statistics:

For most early adopters the impact on financial statements was favorable as stated previously.

The average pension expense for all firms was $\$ 5.4$ million (net) which was relatively small with regard to information provided in the sample. Stone concludes that the reason for this is because 96 of the companies reported pension income (vs. expense). The average amount of pension income reported by these companies was $\$ 12.75$ million. The 
average amount of pension expense reported by the 13I companies that had expense was $\$ 19.63$ million. The average decrease in the amount of pension expense for all companies was $\$ 22.49$ million. On an after tax basis this decrease amounted to approximately $\$ \mathrm{I} 4.89$ million (2I \%) or I8 cents per share; which is quite substantial.

Based on the auditors opinions that accompanied the financial reports of 53\% of the companies in the sample, the impact of the accounting change appears to be significant, otherwise the auditors opinions would not have included a consistency exception for FAS 87.

The income statement effect was even more favorable for the 190 companies that specifically experienced a pension cost decrease. The after tax income of these companies increased by approximately $26 \%$, according to Stone.

Out of the remaining 37 companies only 5 disclosed the amount of the increase in pension expense, the other 32 said the change had no material effect. Stone concludes that most likely, these companies had already been calculating their pension costs using the benefits/years of service method, therefore there was little change. Stone attributes much of the expense savings to the change from other actuarial methods to this one required under FAS 87 (accrued benefits method). She also attributes the pension income that many of the companies reported to the return and gain components of pension cost

Her study indicated that for her sample, the service cost component was the smallest component of pension expense and interest cost was more than twice as large as service cost. She speculates that for those firms having the higher service cost, interest cost, and actual returns and who still reported pension expense rather that income, were probably those companies who sponsored older and larger plans.

She found the net amortization costs to be relatively large and because the calculation added it to cost rather than subtracted it, this indicated to her that the actual return on plan assets was greater than expected return and the deferral of this difference more than offset the amortization of the transition asset

She states that the large size of the actual return on plan assets, $\$ 152.82$ million was due to the favorable stock market conditions in 1986. It represented a return of $17 \%$ on plan assets at the beginning of the period which was substantial when compared to the average long-term expected return of 9.26 as disclosed by the companies in her study.

Based on the disclosed information Stone still found the range of assumptions used by different companies to be quite wide with discount rates ranging from 6.5 to II per-cent although FAS 87 limited their choices.

Expected rates of return ranged from $7 \%$ to $14 \%$ and was comparable to the range reported in 1985 under SFAS 36 although the average had improved and increased from the previously lower rates used in 1985. She could find only minimal correlation between the choice of a discount rate and a return rate selected by these companies. Knowing one rate only explained $10 \%$ of the variation in the selection of the other rate. Additionally, she could find no correlation between interest rates and assumed rates of salary increases.

She also determined that there was considerable differences in the size of the pension plans sponsored by the companies based on very large standard deviations on plan assets and obligations. Also, on the average, she found the projected benefit obligations to be $18 \%$ larger than the accumulated benefit obligation and $28 \%$ greater than the vested benefit obligation.

Asset to obligation ratios yielded the following:

Fair value of plan assets @yr. end $I$ pbo = 1.07 avg. funding status.

Surplus as $\%$ of obligation $=(\mathrm{fV}$ assets $-\mathrm{pbo}) / \mathrm{pbo}$, indicated a $7 \%$ decrease in the fair value of plan assets could eliminate the appearance of overfunding.

Fair value of plan assets@ yr. end $I$ abo 1.30 avg. funding status, indicating that if the plan were terminated the 30\% of assets overfunded were an off-balance sheet source of funding available to the companies if the plans were terminated.

Fair value of plan assets @yr. end $I$ vbo 1.43 avg. funding status, indicating that either the value of vested plan benefits and/or the number of those vested was small.

Eighty-six percent of the early adopters sponsored both over and under funded plans, based on

1.33 as the funding status level at which a plan is considered overfunded and 0.69 for the level at which a plan is considered underfunded.

According to their balance sheets, $95 \%$ of the plans had an accumulated benefit obligation that exceeded their assets. The average minimum liability for this would have been $\$ 62$ million, according to Stone, however only 10 companies indicated that they had recognized same, since PAS 87 didn't require recognition until 1987. 
The Stone study is highly informative Given the magnitude of the amounts and the relative relationships of pension costs, assets and liabilities, determined in this study, the impact of FAS 87 appears to have been highly material for early adopters making it very clear as to why they adopted as early as they did and contributes much support to the observations made in this paper regarding the significance of the state or the economy and the variety of rates and assumptions permitted by FAS 87.

\section{Conclusion}

In this study, we have examined the treatment of pension debts which companies have and the treatment by the accounting profession of those debts. We determine that the new pronouncement is an improvement to what existed before, and we gave reasons for that. Consequently, early adopters enthusiastically did so, since their early adoption implied that the result was beneficial to them.

\section{References}

Ali, Ashlq. (1994). The Magnitude of Financial Statement Effects and Accounting Choice: The Case of Adoption of SFAS 87. Journal of Accounting and Economics, 18(I), (Jul. 1994), 89-J14. https://doi.org/10.1016/0165-4101(94)90020-5

Antle, Rick, Joel S. Demski, Stephen G. Ryan. (1994). Multiple Sources of lnformation, Valuation, and Accounting Earnings. Journal of Accounting, Auditing \& Finance, NS9 (Fall1994): 675-702.

Barth, Mary E., W. Beaver \& W. Landsman. (1993). A Structural Analysis of Pension Disclosures Under SFAS 87 and Their Relationship to Share Prices. Financial Analysts Journal, 49(I), (Jan/Feb. 1993), 18-26. https://doi.org/10.2469/faj.v49.n1.18

Bayer, Freida A., Neil Wilner. (1990). Accounting for Pensions Under FASB 87: A Case Study. The Practical Accountant, 23 (June 1990), 38-50.

Benovitz, David M. (1994). Is Your Pension Plan Worth Less Than You Think? (FASB"87 Discount Rate Method). Financial Executive, 10, (January/February 1994), 30-33.

Bergsman, Steve. (1994). Measuring Up: FASB 's Influence on Pension Plans. Pension Management, 30(Jl), (Nov. 1994), 20-22.

Bleiberg, Steve. (1988). Less Than Zero. Financial Analysts Journal, (March 1988), 13-17.

Carpenter, Dr. Brian W., Dr. Daniel P. Mahoney. (1992). The Enduring Controversy Over Pension Accounting: Are the Current Measures of Pension Assets and Liabilities Misleading? Journal of Applied Business Research, 8(4), (Fall 1992), 30-39. https://doi.org/10.19030/jabr.v8i4.6122

Chen, Yueh H., Winston T. Lin. (1992). Pension Benefits Effects on Capital Market Equilibrium, Firm Value, and Financing Decisions. Journal ofBusiness Research, 25, (August 1992), 1-25.

Cready, William M., Patricia G. Mynatt. (1991). The Information Content of Annual Reports: A Price and Trading Response Analysis, 66(2), (Aprill991), 291-312.

Daley, Lane A., Terry Tranter. (1990). Limitations on the Value of the Conceptual Framework in Evaluating Extant Accounting Standards, 4, (March 1990), 15-24.

Dankner, Harold, Roger Johnson. (1986). SFAS No. 87- Employer's Accounting for Pensions. Cornorate Accounting, 4(3), (Summer 1986), 83-87.

Easton, Peter D., Trevor S. Harris. (1991). Earnings as an Explanatory Variable for Returns, 29, (Spring 1991), 19-36.

Financial Accounting Standards Board of the Financial Accounting Foundation, Statement of Financial Accounting Standards No. 87 Employers Accounting for Pensions. Stamford: Financial Accounting Series (ISSN 0885-90110746-7486) No.12, December 1985.

Gopalakrishnan, V., Timothy F. Sugrue. (1992). Economic Consequences of Pension Policy Deliberations (SFAS NO. 87): An Empirical Assessment of Debt-Covenant Hypothesis. Journal of Business Finance \& Accounting, 19(5), (Sept. 1992), 751-775. https://doi.org/10.1111/j.1468-5957.1992.tb00655.x

Harper, Robert M. Jr., William G. Mister, \& Jerry R. Strawser. (1987). The Impact of New Pension Disclosure Rules on Perceptions ofDebt. Journal of Accounting Research, 25(2), (Autumn 1987), 327-330. https://doi.org/10.2307/2491022

Harper, Robert M., Jerry J. Strawser. (1993). The Effect of SFAS 87 on Corporate Funding ofDefined Benefit Plans. 
Journal of Business Finance \& Accounting, 20(6), (Nov. 1993), 815-833.

Haw, ln-Mu, Kooyul Jung \& Steven B. Lillien. (1991). The Impact of SFAS 88: Puff or Economic Reality? The CPA Journal, (October 1991), 38-4x.

Herdman, Robert K., Robert D. Neary. (1994). What are America's Top Companies Doing About Pensions (since FASB Statement 87) ? Financial Executive, ISSN: 0895-4186, no.6 (Jan./Feb. 1994): 10-13.

Hsieh, Su-Jane, Kenneth R. Ferris. (1994). An Investigation ofOverfunded Pension Plan Terminations. Journal of Accounting Auditing \& Finance, 9(I), (Winter 1994), 61-90. https://doi.org/10.1177/0148558X9400900105

Kiplinger Washington Editors. (1995). The Kiplinger Tax Letter, 70(14), (June 30, 1995).

Langer, Russell, Baruch Lev. (1993). The FASB' s Policy of Extended Adoption for New Standards: An Examination ofFAS No. 87 (accounting for pensions). The Accounting Review, 68, (July 1993), 515-533.

Levit, Alan D. (1989). Underfunded Pension Plans Now Mean More Company Liability. Financial Executive, 5(3), (May/Jun. 1989), 47-50.

Mesmer, M. (1990). SFAS 87: What Effect So Far? Woman CPA 52, no. I (Winter 1990), 9-12. Miner, William J. "Stock Value Decline Affects Pension Costs." Business Insurance

Mittelstaedt, Fred H., Philip R. Regier. (1993). The Market Response to Pension Plan Tenninations. The Accounting Review, 68(I), (January 1993), 1-27.

Munnell, Alice M. (1987). Pension Contributions and the Stock Market. New England Economic Review, (Nov./Dec. 1987), 3-14.

Petree, Thomas R. (1993). Shifting to the Balance Sheet. Business Credit, (Nov./Dec. !993), 28-30.

Revsine, Lawrence. (989). Understanding Financial Accounting Standard 87. Financial Analysts Journal, 45(!), (Jan./Feb. 1989), 6!-68.

Rosenberg, Hilary. (1987). The Mad, Mad World ofFAS 87. Institutional Investor, 21(IO), (Oct. 1987), 191 - 195.

Senteny, David L., Jerry R. Strawser. (1990). An Investigation of the Association Between Financial Statement Effects and Management's Early Adoption of SFAS 87. Review of Business \& Economic Research, 25(2), (Spring 1990), 12-22.

Stone, Mary. (1988). The Effect of Statement No. 87 on the Financial Reports of Early Adopters. Accounting Horizons, 2(3), (Sept. 1988), 48-61.

VanDerhei, Jack L., Francois P. Jeanette. (1988). Economic Determinants for the Choice of Actuarial Cost Methods. Journal of Risk and Insurance, 55(I), (Mar. 1988), 59-74. 


\section{Notes}

Note 1. The Accounting Principles Board issued Opinion No. 8 in 1966. It contained several views of pension accounting supported by the APB. Later, in May of 1980 SFAS No. 36 was issued which amended Opinion 8 and also established a disclosure standard based of requirements identified in SFAS NO. 35. FAS 35 identified the accounting and reporting requirements for the actual Defined Benefit Plan (VS. the sponsoring Employers. Both $3 \mathrm{j} \& 36$ were implemented as a result of a changing pension environment, primarily resulting from Government regulations (Employee Retirement Income Security Act).

Note 2. FAS No. 88 will also be discussed in conjtmction with No.87, when applicable..

Note 3. Financial Accounting Standards Board .. No. 012, Financial Accounting Series: Statement of Financial Accounting Standards No.8?. (Stamford, Ct., Dec. 1985).

Revsine, Lawrence. "Understanding Financial Accounting Standard 87." Financial Analysts Journal45, no. I (Jan./Feb. 1989): 61-68.

Bayer, Freida A., Neil Wilner. "Accounting for Pensions Under FASB 87: A Case Study." The

Practical Accountant 23 (June 1990): 38-50.

Note 4. John E. Pmvers, Senior V.P. of Eagle-Picher Industries was quoted as saying this according to a study, entitled '"Limitations on the Value of the Conceptual Framework in Evaluating Extant Accounting Standards" by Lane A. Daley and Terry Tranter, published in Accounting Horizons Volume 4 (March 1990).

Note 5 . See the Overview Section for details of this calculation.

Note 6. VanDerhei, Jack L.; Jeanette, Francois P. "Economic determinants for the choice of actuarial cost methods." Journal of Risk \& Insurance 55, 1 (Mar. 1988): 59-74.

Note 7. It was also noted in this study that where cash was a concern to a corporation it too may be the primary motivating factor, however this factor was not covered in their study.

Note 8. Gopalakrishnan, V.: Sugrur Timothy F. "Economic Consequences of Pension Policy Deliberations (SFAS NO. 87):

An Empirical Assessment of Debt-Covenant Hypothesis." Journal of Business and Finance. 9, 5 (Sept. 1992): 751-775.

Note 9. Herdman, Robert K., Robert D. Neary. "What are Americas Top Companies Doing About Pensions since FASB Statement 87) ?" Financial Executive ISSN: 0895-4!86, no.6 (Jan./Feb. !994): 10-13.

Note 10. Our basis for this observation also includes literature that had been reviewed but not used for this Section of the paper. 